\title{
Effect of nitrate supply and mycorrhizal inoculation on characteristics of tobacco root plasma membrane vesicles
}

\author{
Martin Moche $\cdot$ Stefanie Stremlau $\cdot$ Lars Hecht $\cdot$ \\ Cornelia Göbel · Ivo Feussner · Christine Stöhr
}

Received: 28 July 2009/Accepted: 4 November 2009/Published online: 25 November 2009

(C) The Author(s) 2009. This article is published with open access at Springerlink.com

\begin{abstract}
Plant plasma membrane (pm) vesicles from mycorrhizal tobacco (Nicotiana tabacum cv. Samsun) roots were isolated with negligible fungal contamination by the aqueous two-phase partitioning technique as proven by fatty acid analysis. Palmitvaccenic acid became apparent as an appropriate indicator for fungal membranes in root pm preparations. The pm vesicles had a low specific activity of the vanadate-sensitive ATPase and probably originated from non-infected root cells. In a phosphate-limited tobacco culture system, root colonisation by the vesicular arbuscular mycorrhizal fungus, Glomus mosseae, is inhibited by external nitrate in a dose-dependent way. However, detrimental high concentrations of $25 \mathrm{mM}$ nitrate lead to the highest colonisation rate observed, indicating that the defence system of the plant is impaired. Nitric oxide formation by the pm-bound nitrite:NO reductase increased in parallel with external nitrate supply in mycorrhizal roots in comparison to the control plants, but decreased under excess nitrate. Mycorrhizal pm vesicles had roughly a twofold higher specific activity as the non-infected control plants when supplied with $10-15 \mathrm{mM}$ nitrate.
\end{abstract}

Keywords Mycorrhiza $\cdot$ Nitric oxide . Nitrite:NO reductase $\cdot$ Palmitvaccenic acid . Plasma membrane $\cdot$ Root

M. Moche · S. Stremlau · L. Hecht · C. Stöhr $(\bowtie)$

Institute of Botany and Landscape Ecology,

Greifswald University, Grimmer Str. 88,

17487 Greifswald, Germany

e-mail: stoehr@uni-greifswald.de

C. Göbel · I. Feussner

Plant Biochemistry, Georg-August-University,

Justus-von-Liebig-Weg 11, 37077 Göttingen, Germany

\author{
Abbreviations \\ AM Arbuscular mycorrhiza \\ NI-NOR Nitrite:NO reductase \\ pm Plasma membrane
}

\section{Introduction}

Arbuscular mycorrhizae (AM) are widespread mutualistic symbioses between most of the terrestrial plants and fungi of the phylum Glomeromycota (Schüßler et al. 2001). The mutualistic association sets up a strategy to improve the nutritional status of both partners. The fungi receive fixed carbon compounds, mainly in the form of glucose (Schüßler et al. 2007) from the host plant, whilst the plant benefits from the association by increased nutrient uptake, especially phosphate (reviewed by Ezawa et al. 2002) and nitrogen (Govindarajulu et al. 2005), as well as water (reviewed by Uehlein et al. 2007). Improved tolerance to abiotic stress and resistance to pests have been also noted (reviewed by Pozo and Azcón-Aguilar 2007).

Formation of mycorrhizal symbiosis

During the first steps of mycorrhizal colonisation, the extracellular fungal hyphae approach the root surface to form appressoria. During this process, several changes occur in the cellular organisation of the underlying epidermal root cell (reviewed by Reinhardt 2007). The nucleus transitionally migrates to a position below the appressorium. This causes an aggregation of microtubules, actin microfilaments and ER cisternae that become organised to a pre-penetration apparatus and defines the 
colonisation path for the invading fungal hypha (Genre et al. 2005). Activation of specific genes has been noted during this process (Siciliano et al. 2007). When the extracellular hyphae grow into the root cortex, intracellular arbuscules are formed at individual cortical root cells within a few days (Albrecht et al. 1999). One intriguing question is how neighbouring root cells regulate the formation of a pre-penetration apparatus, whereas the adjacent cell is not infected.

Arbuscules are separated from the cytoplasm by the host plasma membrane (pm). This periarbuscular membrane may amplify the area up to tenfold in colonised cells (Smith and Smith 1990). With arbuscule development, the cell wall of the fungus becomes thinner and an interface for nutrient exchange between plant and fungus is formed (Harrison 1999). The plant cell becomes cytoplasmically dense, its vacuole fragments, and the number of Golgi bodies increases, whereby the nucleus moves to a more central position (Balestrini et al.1992).

Considerable progress has been made in understanding the mechanisms controlling the arbuscular mycorrhizal development (reviewed by Reinhardt 2007). Plant-derived strigolactones have been identified as presymbiotic signals to induce hyphal branching in germinating mycorrhizal spores (Akiyama et al.2005). Evidence suggests that as in plant-pathogen interactions, the induction/suppression of mechanisms associated with plant defence are also important in AM fungal colonisation and compatibility with its host. Events similar to those found in plant-pathogen interactions have been also found in the plant in contact with AM fungi (García-Garrido and Ocampo 2002). These events include signal perception, signal transduction and defence gene activation. For establishment of mutualistic associations, modulations in plant defence responses are required (Pozo and Azcón-Aguilar 2007) that potentially occur through a cross-talk between salicylic acid and jasmonate-dependent signalling pathways (reviewed by Hause et al. 2007). Changes in plant membrane integrity have been proposed as an explanation by which plants can regulate colonisation (Bonfante and Perotto 1995). One possibility might be the emission of nitric oxide (NO), which has been shown to be produced specifically at the pm of roots (Stöhr et al. 2001). The role of NO during plant defence is one of the first functions that has been recognised (Delledonne et al. 1998; Durner et al.1998), including salicylic acid-dependent signalling events and the development of a systemic acquired resistance (Klessig et al. 2000). A putative role of NO during mycorrhiza, possibly via elevating $\mathrm{Ca}^{2+}$ influx, has been suggested by Weidmann et al. (2004), who found an activation of one nitrate reductase gene before establishment of symbiosis between Medicago truncatula and Glomus mosseae. These processes may affect pathogens along with mycorrhizal fungi, leading to a poor or even no colonisation of the plant.

Mycorrhiza is dependent on nutrient status

Control of fungal root colonisation by plants has been observed in relation to nutrient status of the soil (Eriksson 2001). Several studies (e.g. Menge et al. 1978; Duke et al. 1994) have indicated that host plants can lessen mycorrhizal colonisation when phosphorus level in the soil is either very low or very high, and the benefits of mycorrhizal associations are negligible. Besides phosphate, the nitrogen availability in the soil is critical to plant growth. It has been reported that extraradical hyphae take up inorganic nitrogen and transport it to intraradical hyphae in the form of amino acids (Govindarajulu et al. 2005). There, it is released in the form of ammonia into the apoplast where it can be used by the cells of the root (Chalot et al. 2006). In addition, the transport of nitrate via mycorrhizal fungi to the host plant has been demonstrated preferentially under drought when nitrate diffusion in the soil is reduced (Tobar et al. 1994).

The stimulating influence of moderate external nitrate concentration on plant growth, accompanied by enhanced activity of root pm enzymes, was demonstrated earlier as the cause of NO production by the root (Stöhr 1999; Stöhr and Stremlau 2006). The substrate for this purpose is nitrate, which is apoplastically reduced to nitrite by the plasma membrane-bound nitrate reductase (PM-NR). Subsequently, the nitrite is further reduced to NO by the nitrite:NO reductase (NI-NOR). So far, the behaviour of these enzymes under conditions of shortage of phosphate together with sufficient nitrogen availability, and whether there is a correlation with mycorrhizal colonisation are unknown.

Properties of plasma membranes in mycorrhizal roots

Isolation of root pm vesicles from mycorrhizal roots is a particular challenge due to the risk of contamination by fungal membranes and the uncertainty of the origin of membranes (cells with or without arbuscules, for example, periarbuscular membrane). Recently, mycorrhizal root pm vesicles were enriched by sucrose gradient centrifugation (Valot et al. 2006; Ramos et al. 2009). Because of the applied technique, those vesicles were contaminated by various plant endomembranes. Nevertheless, Valot et al. succeeded in identifying mycorrhiza-specific pm ATPase and a blue copper-binding protein, which could serve as marker for periarbuscular membranes. The two-phase partitioning technique results in a high enrichment of rightside-out pm vesicles of non-symbiotic roots in the upper polyethylene glycol-enriched phase, whereas the inside-out orientated $\mathrm{pm}$ vesicles have higher affinity to the lower 
dextran phase (Larsson 1985). This property can be used to gain $\mathrm{pm}$ vesicles from mycorrhizal roots without contamination by plant endomembranes. Fungi contain a mannoprotein layer, which lies in the interface between the pm and the cell wall, acting as structural attachment (Shepherd 1987). This causes the formation of inverse-orientated pm vesicles or a pm sheet after mechanical disruption of the cell (Menéndez et al. 1995). For that reason, the isolated 'right-side-out'-oriented plant pm vesicles should be free of fungal contamination.

The lipid fatty acid, palmitvaccenic acid $\left(16: 1^{\Delta 11 \mathrm{Z}}\right)$, is found in high proportions in AM fungi and has been used widely as a signature for AM fungal lipids (e.g. Olsson and Johansen 2000; van Aarle and Olsson 2003; Trépanier et al. 2005). This fatty acid piles up in roots during AM colonisation and the amount accumulated is correlated to microscopically estimated measures of total root colonisation (Olsson et al. 1997). In the phospholipid fraction of AM fungi, palmitvaccenic acid has been also detected (van Aarle and Olsson 2003) and the amount correlated with the occurrence of arbuscules.

In this study, we demonstrate the effect of $\mathrm{N}$ availability under low phosphate condition on root colonisation of tobacco plants by G. mosseae. Variations in fatty acid composition and enzyme activities of root pm have been analysed. We will show that NO-producing capacity of root pm vesicles is strongly correlated with fungal colonisation rate. Palmitvaccenic acid was used successfully as an indicator for fungal lipids in membrane preparation of mycorrhizal roots.

\section{Materials and methods}

\section{Plant material}

Tobacco seeds (Nicotiana tabacum L. cv. Samsun; originally received from Genbank, Gatersleben, Germany) were surface sterilised and incubated for 11 days with $0.5 \mathrm{mM}$ $\mathrm{CaSO}_{4}$. The seedlings were transferred to sand culture (pot diameter of $12 \mathrm{~cm}$ ) in a greenhouse (light/dark rhythm 16/ $8 \mathrm{~h}$ and $\left.28 / 22^{\circ} \mathrm{C}\right)$ with $1 \mathrm{mM} \mathrm{Ca}\left(\mathrm{NO}_{3}\right)_{2}$ as the nitrogen source in Hoagland's nutrient solution containing only $0.1 \mathrm{mM} \mathrm{KH}_{2} \mathrm{PO}_{4}$ (pH 5.5). Potassium was supplied in the form of $3 \mathrm{mM} \mathrm{K}_{2} \mathrm{SO}_{4}$, together with $1 \mathrm{mM} \mathrm{MgSO}$ and microelements, including $\mathrm{Fe}$-citrate. Half of the plants

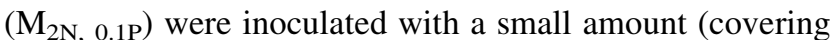
the tip of a spatula) of $G$. mosseae spore granulate BEG 12 (Biorize, Bretenière, France), whilst the other half $\left(\mathrm{NM}_{2 \mathrm{~N}}\right.$, $0.1 \mathrm{P})$ was not inoculated. After 3 weeks, the seedlings were supplied with different nitrate concentrations in nutrient solution ranging from $2 \mathrm{mM}$ nitrate (the lowest concentration without serious nitrogen deficiency symptoms) to
$25 \mathrm{mM}$ given as $\mathrm{Ca}\left(\mathrm{NO}_{3}\right)_{2}$. An additional control experiment was performed with plants receiving during the first 3 weeks of growth $3 \mathrm{mM}$ phosphate and $5 \mathrm{mM}$ nitrate, followed by $3 \mathrm{mM}$ phosphate and $10 \mathrm{mM}$ nitrate without inoculation $\left(\mathrm{NM}_{10 \mathrm{~N}, 3 \mathrm{P}}\right)$ to discriminate between effects due to better nutrient supply from those of mycorrhization $\left(\mathrm{M}_{2 \mathrm{~N}, 0.1 \mathrm{P}} ; \mathrm{NM}_{2 \mathrm{~N}, 0.1 \mathrm{P}}\right)$. After $70-75$ days of growth when plants were still in the vegetative stage, they were harvested in the morning (3rd hour of light). All analyses and enzyme preparations were performed at the same hour of day.

AM fungal root colonisation assessment

The root samples were carefully washed under running water to remove sand. Roots were cleared at $90^{\circ} \mathrm{C}$ in $10 \%$ $\mathrm{KOH}$ for $25 \mathrm{~min}$ and stained with $0.045 \%$ trypan blue for $1 \mathrm{~h}$ and destained overnight in 50\% lactic acid (according to Vierheilig et al. 2005). Samples were stored in lactic acid, glycerol and water (1:1:1, by vol). The colonisation rate was quantified using a line intersect method $(200 \times$ magnification) (McGonigle et al.1990) counting at least 150 intersect points of presence or absence of colonisation in each sample. A rate of colonisation of 1 indicates that the root was colonised by the fungus on the whole length, as indicated by arbuscules or intraradical hyphae.

\section{Preparation of plasma membrane vesicles}

Roots were carefully washed and homogenised. The pm vesicles were purified from the microsomal fraction by partitioning in the aqueous polymer two-phase system as reported by Stöhr and Ullrich (1997). Each final phase of polyethylene glycol (containing right-side-out pm vesicles) and dextran (containing inside-out pm vesicles and endomembranes) was collected, ultracentrifuged and membrane vesicles were resuspended in $0.33 \mathrm{M}$ sucrose, $1 \mathrm{mM}$ DTT, $1 \mathrm{mM}$ EDTA and $5 \mathrm{mM}$ Tris of $\mathrm{pH}$ 7.8. Aliquots were stored at $-70^{\circ} \mathrm{C}$. Vesicles used for all experiments were thawed only once. We refer to the polyethylene glycol phase as pm vesicles consistently.

\section{General analytical methods}

Protein in the fraction was determined according to Bradford (1976) in the presence of $0.1 \%$ octylglucoside with bovine serum albumin as a protein standard. Basic incubation medium composition for ATPase assays (unless otherwise indicated) for measuring inorganic phosphate release was $3.75 \mathrm{mM}$ ATP, $4 \mathrm{mM} \mathrm{MgCl}{ }_{2}, 140 \mu \mathrm{M}$ sodium molybdate, $0.05 \%$ (w/v) Brij 58, $50 \mathrm{mM} \mathrm{KCl}, 50 \mathrm{mM}$ Mes-BTP, pH 6.5 and $0.2-1.0 \mu \mathrm{g}$ protein at $37^{\circ} \mathrm{C}$ according to Hodges and Leonard (1974). The released phosphate 
was determined according to Lanzetta et al. (1979). Plasma membrane vanadate-sensitive $\left(\mathrm{Mg}^{2+}-\mathrm{K}^{+}\right)$-ATPase was determined in basic incubation medium. An aliquot of freshly prepared orthovanadate was added to inhibit enzymatic activity, to give a final concentration of $0.1 \mathrm{mM}$. Tonoplast presence was determined by measuring $\mathrm{K}^{+}$stimulated nitrate-sensitive ATPase activity. The basic incubation medium contained $8.5 \mathrm{mM} \mathrm{K}_{2} \mathrm{SO}_{4}$ instead of $\mathrm{KCl}, 100 \mathrm{mM} \mathrm{NaNO}_{3}$ and $0.1 \mathrm{mM} \mathrm{Na}_{3} \mathrm{VO}_{4}$ in the absence or presence of $0.05 \%(\mathrm{w} / \mathrm{v})$ Brij 58. Azide-sensitive ATPase as a marker for mitochondrial membranes was tested in the basic medium with $4.25 \mathrm{mM}$ azide to inhibit enzyme activity. Cytochrome c oxidase can be also used as marker enzyme for mitochondria. The incubation medium was composed of $50 \mu \mathrm{M}$ cytochrome c reduced by ascorbate, $0.05 \%$ Triton $\mathrm{X}-100$ and $50 \mathrm{mM}$ Tris- $\mathrm{HCl}, \mathrm{pH} 7.5$ at $25^{\circ} \mathrm{C}$ (according to Hodges and Leonard 1974). The reaction was monitored at $556 \mathrm{~nm}$ for $30 \mathrm{~min}$. The presence of Golgi membrane vesicles was determined according to Surjus and Durand (1996), by measuring latent inosine-5'diphosphatase activity (IDPase). The reaction medium also contained $5 \mathrm{mM}$ IDP and $50 \mathrm{mM} \mathrm{KCl}$ in the presence and absence of $0.1 \%(\mathrm{w} / \mathrm{v})$ Triton X-100.

\section{Activities of plasma membrane-bound nitrite:NO} reductase

Recording of NO formation by chemiluminescence detection was performed as described by Stöhr et al. (2001) under anoxic condition. Nitrogen gas (5.0) was first passed through deionized water and then through the glass chamber with a constant flow of $0.41 \mathrm{~min}^{-1}$. The sample was continuously stirred at $30^{\circ} \mathrm{C}$ in a final volume of $500 \mu$ l Hepes-buffer $(0.025 \mathrm{M})$ with $\mathrm{Mes}(0.05 \mathrm{M})$ adjusted to $\mathrm{pH} 6.0$ with $\mathrm{NaOH}$ in the presence of $\mathrm{NaNO}_{2}$ $(1 \mathrm{mM})$ and reduced cytochrome $\mathrm{c}$ (final concentration $0.5 \mathrm{mg} \mathrm{ml}^{-1}$ ). The reaction was started by the addition of pm vesicles derived from the PEG fraction (according to $30 \mu \mathrm{g}$ pm protein). NO was measured by chemiluminescence intensity (CLD 88 ep, Eco Physics, Duernten, Switzerland), and fluxes were calculated from concentration differences before and after the addition of pm vesicles.

\section{Determination of fatty acids}

Lipids were extracted from the membrane vesicles with two volume of methanol:chloroform $(1: 1, \mathrm{v} / \mathrm{v})$ containing $0.5 \mu \mathrm{g}$ of triheptadecanoate as internal standard for quantification of the lipid-bound fatty acids. After vigorous shaking and subsequent centrifugation $(16,000 \mathrm{~g}$ for $5 \mathrm{~min})$, the lower phase was dried under streaming nitrogen. For analysis of the lipid-bound fatty acids, $330 \mu$ l of toluene methanol $(1: 2, \mathrm{v} / \mathrm{v})$ and $170 \mu \mathrm{l}$ of $0.5 \mathrm{mM}$ sodium methoxide solution (Sigma, Deisenhofen, Germany) were added. The sample was shaken for $20 \mathrm{~min}$ and $500 \mu \mathrm{l}$ of saturated sodium chloride solution and $20 \mu \mathrm{l}$ of $32 \%$ (v/v) hydrochloric acid were added. The resulting fatty acid methyl esters were extracted twice with $1 \mathrm{ml}$ of hexane, and the combined organic phases were dried under streaming nitrogen. The remaining fatty acid methyl esters were redissolved in $20 \mu \mathrm{l}$ of acetonitrile and analysed with an Agilent (Waldbronn, Germany) 6890 gas chromatograph fitted with a capillary DB-23 column $(30 \mathrm{~m} \times 0.25 \mathrm{~mm}$, $0.25 \mu \mathrm{m}$ coating thickness; J\&W Scientific, Agilent). Helium was used as carrier gas $\left(1 \mathrm{ml} \mathrm{min}^{-1}\right)$. The temperature gradient was $150^{\circ} \mathrm{C}$ for $1 \mathrm{~min}, 150-200^{\circ} \mathrm{C}$ at $8 \mathrm{~K} \mathrm{~min}^{-1}, 200-250^{\circ} \mathrm{C}$ at $25 \mathrm{~K} \mathrm{~min}^{-1}$ and $250^{\circ} \mathrm{C}$ for $6 \mathrm{~min}$.

\section{Results}

Growth response and colonisation of tobacco roots by G. mosseae in dependence on nitrate supply

As indicator for growth response, shoot biomasses of mycorrhizal $\left(\mathrm{M}_{2 \mathrm{~N}, 0.1 \mathrm{P}}\right)$ and non-mycorrhizal $\left(\mathrm{NM}_{2 \mathrm{~N}, 0.1 \mathrm{P}}\right)$ plants were analysed on the day of harvest. No differences in shoot fresh weight were noted between mycorrhizal and non-mycorrhizal plants (Fig. 1). Phosphate concentration in the medium is critical for establishing mycorrhizal symbiosis (Furlan and Bernier-Cardou 1989). Since $1 \mathrm{mM}$ phosphate was sufficient to completely inhibit tobacco root colonisation with $G$. mosseae even under nitrogen

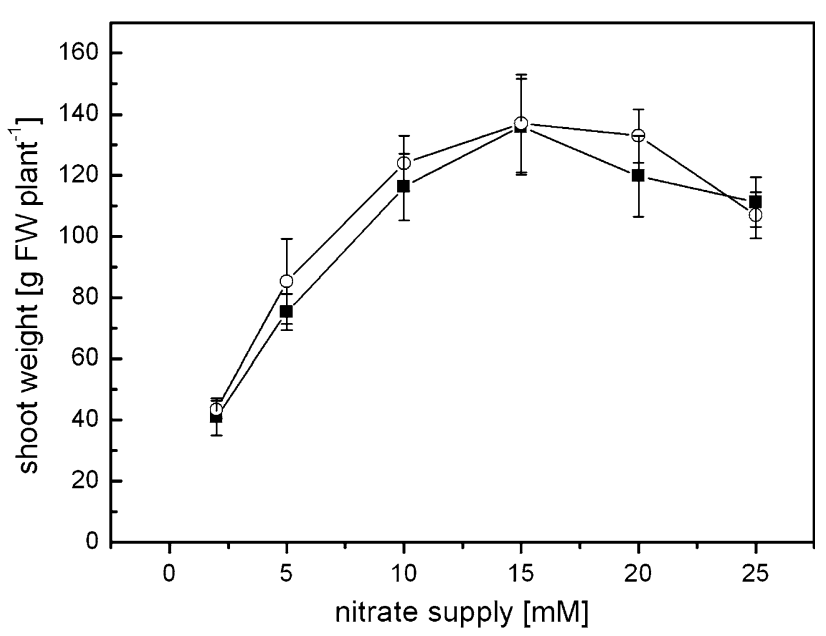

Fig. 1 Shoot fresh weight based on nitrate supply and mycorrhizal infection. Mycorrhizal (open circle) and non-mycorrhizal (filled squares) plants were grown under different nitrate regime, and shoot fresh weight as indicator for biomass production was determined on the day of harvest (after 70-75 days). Mean values $\pm \operatorname{SD}(n=5)$ 
limitation ( $2 \mathrm{mM}$ nitrate) (data not shown), the plants were cultivated under phosphate-limiting conditions $(0.1 \mathrm{mM})$.

Calculation of the colonisation rate is based on the presence of arbuscules and intraradical hyphae (Fig. 2a). The number of vesicles was not included in the diagram, since it was very low under all nutrient conditions (e.g. highest vesicle colonisation rate of $0.02 \pm 0.03$ at concentration of $2 \mathrm{mM}$ nitrate). A good colonisation rate of tobacco roots was achieved under nitrogen limitation at 2$5 \mathrm{mM}$ nitrate and decreased in parallel to improvement in nitrogen supply. Interestingly, the colonisation rate increased enormously with supra-optimal nitrate supply when the plants showed reduced growth parameters (Fig. 1, see also Stöhr 1999). Under the applied growing condition, $2 \mathrm{mM}$ was the lowest nitrate concentration to cultivate plants, although it revealed serious deficiency symptoms.
Characteristics of plasma membrane vesicles

\section{Enzymatic marker activities}

Membranes of the microsomal fractions of mycorrhizal $\left(\mathrm{M}_{2 \mathrm{~N}, 0.1 \mathrm{P}}\right)$ and non-mycorrhizal $\left(\mathrm{NM}_{2 \mathrm{~N}, 0.1 \mathrm{P}}\right)$ tobacco roots grown under limited nitrate $(2 \mathrm{mM})$ and phosphate $(0.1 \mathrm{mM})$ in addition to non-mycorrhizal plants grown under sufficient nutrient conditions $(10 \mathrm{mM}$ nitrate, $3 \mathrm{mM}$ phosphate, $\mathrm{NM}_{10 \mathrm{~N}, 3 \mathrm{P}}$ ) were separated by the two-phase partitioning technique resulting in a dextran and polyethylene glycol-enriched fraction (Fig. 3). Marker enzyme activities were assayed in all fractions to estimate contaminations by endomembranes in the pm fraction (PEG fraction). The pm vesicles (refer throughout the text to PEG fraction) from plants well supplied with nutrients $\left(\mathrm{NM}_{10 \mathrm{~N}, 3 \mathrm{P}}\right)$ showed an enrichment in vanadate-inhibited a
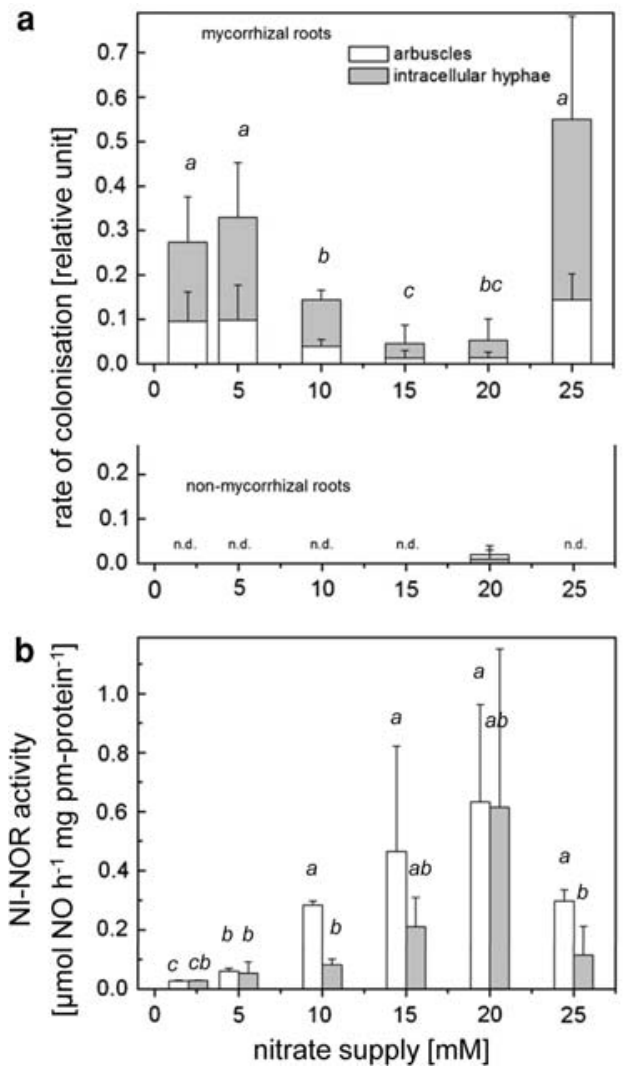

Fig. 2 Activities of plasma membrane-bound nitrite-NO reductase (NI-NOR) of mycorrhizal and non-mycorrhizal roots in dependence on nitrate supply and colonisation rate. Tobacco plants were grown under limited phosphate regime $(0.1 \mathrm{mM})$ with nutrient solution ranging from 2 to $25 \mathrm{mM} \mathrm{NO}_{3}{ }^{-}$as indicated a. Colonisation rate is presented in relative units $(1$ corresponds to maximal theoretical mycorrhiza infection). As controls, also the non-mycorrhizal plants were studied for fungal infection. Proportions of arbuscules and intracellular hyphae are presented. n.d. not detected. b Plasma

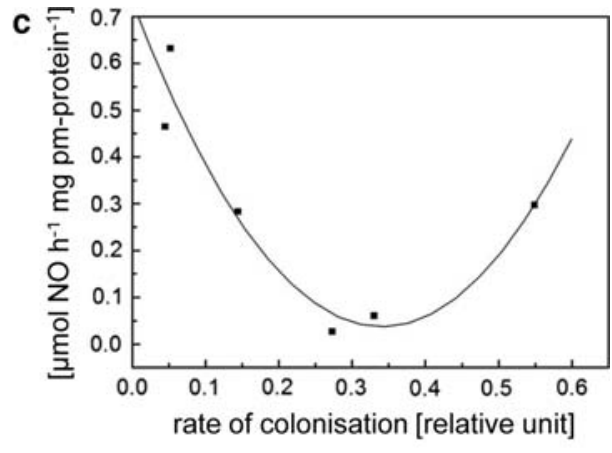

membrane vesicles (derived from the PEG phase) were prepared with the two-polymer phase system from mycorrhizal (open bars) and nonmycorrhizal (filled bars) roots. NO formation is shown in the presence of $\mathrm{NaNO}_{2}(1 \mathrm{mM})$ and reduced cytochrome c. c Polynomial correlation between NI-NOR activity and colonisation rate by $G$. mosseae. Data represent means from three independent experiments with three replicates per treatment and are tested with multiple $t$ tests at the significance levels of $P \leq 0.05$. Bars represent the mean \pm SD $(n=9)$. Means sharing the same letters are not significantly different 
Expected membrane vesicles:

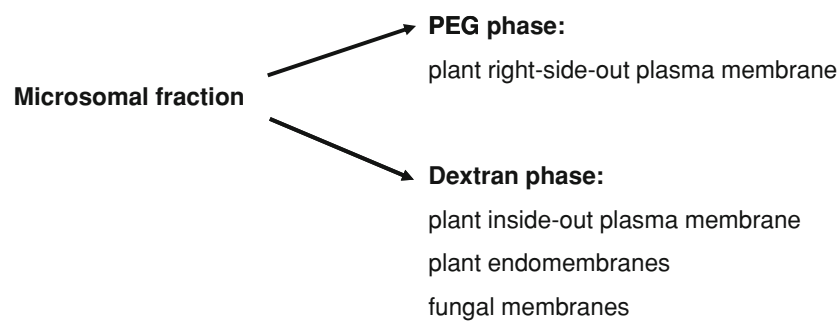

Fig. 3 Overview of membrane vesicles separation with aqueous twophase system. Microsomal root fractions of mycorrhizal and nonmycorrhizal plants were added to the aqueous two-phase system and separated into a polyethyleneglycol-rich phase (PEG phase) and a dextran-rich phase. The expected partitioning of the membrane vesicles is indicated

$\mathrm{H}^{+}$-ATPase activity (pm marker) of 2.6 to the initial microsomal fraction (Table 1). In comparison, the specific activity of vanadate-inhibited $\mathrm{H}^{+}$-ATPase in nitrogen and phosphate-limited roots was much lower in the microsomal fraction. Notwithstanding, the specific activity of the vanadate-inhibited $\mathrm{H}^{+}$-ATPase was 1.6-fold increased in the mycorrhizal microsomal fraction in comparison to nonmycorrhizal roots.

Tonoplast contamination of the pm vesicles was very low as indicated by the minor activity of the nitrateinhibited $\mathrm{H}^{+}$-ATPase in the mycorrhizal pm fraction and it was not detectable in PEG fractions isolated from nonmycorrhizal roots. Mitochondrial contamination as measured by cytochrome c oxidase and azide-sensitive ATPase was negligible in all pm preparations (PEG fractions). Only the marker enzyme for the Golgi apparatus (latent inosine$5^{\prime}$-diphosphatase) was present with a notable activity in the pm fraction. Since Golgi vesicles are the source of the pm itself, this might reflect the high productivity or turnover at the pm of roots with nutrient deficiency.

\section{Fatty acid composition of plasma membrane vesicles}

Membrane fractions isolated from mycorrhizal $\left(\mathrm{M}_{2 \mathrm{~N}, 0.1 \mathrm{P}}\right)$ and non-mycorrhizal $\left(\mathrm{NM}_{2 \mathrm{~N}, 0.1 \mathrm{P}}\right)$ tobacco roots grown under limited nitrate and phosphate as well as under sufficient nutrient conditions $\left(\mathrm{NM}_{10 \mathrm{~N}, 3 \mathrm{P}}\right)$ were used for fatty acid analysis. The major fatty acids recovered in all fractions were palmitic (16:0), linoleic (18:2) and $\alpha$-linolenic (18:3) (Table 2). Relative percentages of those fatty acids varied only slightly between $\mathrm{pm}$ and endomembranes of the roots and did not vary between mycorrhizal and nonmycorrhizal roots or by the additional supply of $\mathrm{N}$ and $\mathrm{P}$. Together, they made up about $85 \%$ of the total fatty acid composition of membrane lipids. The ratio of fatty acid proportion in pm between mycorrhizal and non-mycorrhizal plants $\left(\mathrm{M}_{2 \mathrm{~N}, 0.1 \mathrm{P}} / \mathrm{NM}_{2 \mathrm{~N}, 0.1 \mathrm{P}}\right)$ together with that between well supplied plants and those with restricted supply of $\mathrm{N}$ and $\mathrm{P}\left(\mathrm{NM}_{10 \mathrm{~N}, 3 \mathrm{P}} / \mathrm{NM}_{2 \mathrm{~N}, 0.1 \mathrm{P}}\right)$ can be used as indicator to discriminate between a true mycorrhizal effect and those caused by improved nutrition (Table 3). Palmitvaccenic acid was enriched in the microsomal and the pm fraction (PEG fraction) depending on the degree of colonisation. Amongst all fatty acids, it was palmitvaccenic acid, which was specifically enriched in mycorrhizal pm fractions. On comparing the distribution of palmitvaccenic acid between the dextran and the PEG fraction, it became obvious that the fungal membranes had a much higher affinity to the dextran fraction (Table 4). The equal distribution of the very low proportion of palmitvaccenic acid in the nonmycorrhizal plants indicates an unspecific background. Limitation in $\mathrm{N}$ and/or $\mathrm{P}$ metabolism seems to affect the

Table 1 Biochemical characterisation of purified pm vesicles (PEG fraction) from differently cultivated tobacco roots

\begin{tabular}{|c|c|c|c|c|c|c|c|c|c|}
\hline \multirow[t]{2}{*}{ Enzyme activity } & \multicolumn{3}{|l|}{$\mathrm{M}_{2 \mathrm{~N}, 0.1 \mathrm{P}}$} & \multicolumn{3}{|l|}{$\mathrm{NM}_{2 \mathrm{~N}, 0.1 \mathrm{P}}$} & \multicolumn{3}{|l|}{$\mathrm{NM}_{10 \mathrm{~N}, 3 \mathrm{P}}$} \\
\hline & MF & Dex-F & PEG-F & MF & Dex-F & PEG-F & MF & Dex-F & PEG-F \\
\hline $\begin{array}{l}\text { Vanadate-sensitive } \\
\mathrm{H}^{+} \text {-ATPase }\end{array}$ & $15.2 \pm 5.2$ & $20.9 \pm 1.9$ & $6.8 \pm 2.4$ & $9.3 \pm 1.0$ & $11.9 \pm 3.6$ & $11.5 \pm 1.4$ & $25.8 \pm 11.1$ & $19.9 \pm 3.5$ & $67.7 \pm 8.1$ \\
\hline Nitrate-sensitive $\mathrm{H}^{+}$-ATPase ${ }^{\mathrm{a}}$ & $6.9 \pm 2.4$ & $6.3 \pm 1.5$ & $0.1 \pm 0.3$ & $3.9 \pm 1.1$ & $3.3 \pm 1.2$ & ND & $14.8 \pm 2.6$ & NM & ND \\
\hline Azide-sensitive $\mathrm{H}^{+}$-ATPase ${ }^{\mathrm{a}}$ & $7.4 \pm 3.6$ & $7.9 \pm 2.5$ & ND & $4.8 \pm 1.2$ & $4.8 \pm 0.7$ & ND & $62.0 \pm 4.5$ & $39.8 \pm 6.0$ & ND \\
\hline Cyt $c$ oxidase $^{\mathrm{b}}$ & $6.0 \pm 1.9$ & $14.6 \pm 0.9$ & ND & $3.6 \pm 0.9$ & $10.8 \pm 1.5$ & ND & $6.2 \pm 2.8$ & $21.7 \pm 1.9$ & ND \\
\hline IDPase latency $^{\mathrm{a}}$ & $21.4 \pm 5.3$ & $15.8 \pm 2.7$ & $7.4 \pm 1.4$ & $22.8 \pm 3.4$ & $19.6 \pm 3.1$ & $9.1 \pm 3.1$ & $8.1 \pm 2.1$ & $12.1 \pm 1.1$ & $2.8 \pm 1.5$ \\
\hline
\end{tabular}

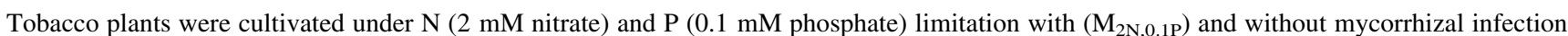
$\left(\mathrm{NM}_{2 \mathrm{~N}, 0.1 \mathrm{P}}\right)$. As control $\left(\mathrm{NM}_{10 \mathrm{~N}, 3 \mathrm{P}}\right)$, also plants with sufficient $\mathrm{N}(10 \mathrm{mM}$ nitrate) and $\mathrm{P}(3 \mathrm{mM}$ phosphate) were tested. The pm vesicles were isolated using an aqueous two-phase partitioning system. Marker enzyme activities of the microsomal (MF), dextran (Dex-F) and PEG (PEG-F) fraction (pm fraction) are presented. Data represent mean values $\pm \mathrm{SD}(n=3)$

$N D$ Not detected, $N M$ not measured

${ }^{\text {a }}$ Enzyme activities are expressed as $\mu \mathrm{mol} \mathrm{PO}_{4}{ }^{3-} \mathrm{h}^{-1} \mathrm{mg}$ protein ${ }^{-1}$

${ }^{\mathrm{b}}$ Enzyme activities are expressed as nmol Cyt $c \min ^{-1} \mathrm{mg}_{\text {protein }}{ }^{-1}$ 
Table 2 Fatty acid composition in membrane fractions of tobacco roots under different nutrient regime and colonised by $G$. mosseae

\begin{tabular}{|c|c|c|c|c|c|c|c|}
\hline \multirow[t]{3}{*}{ Fatty acid } & \multicolumn{7}{|c|}{ Molar percentage $^{\mathrm{a}}$} \\
\hline & \multicolumn{2}{|c|}{ Microsomal fraction } & \multicolumn{2}{|c|}{ Dextran fraction } & \multicolumn{3}{|c|}{ Polyethyleneglycol fraction } \\
\hline & $\mathrm{NM}_{2 \mathrm{~N}, 0.1 \mathrm{P}}$ & $\mathrm{M}_{2 \mathrm{~N}, 0.1 \mathrm{P}}$ & $\mathrm{NM}_{2 \mathrm{~N}, 0.1 \mathrm{P}}$ & $\mathrm{M}_{2 \mathrm{~N}, 0.1 \mathrm{P}}$ & $\mathrm{NM}_{2 \mathrm{~N}, 0.1 \mathrm{P}}$ & $\mathrm{M}_{2 \mathrm{~N}, 0.1 \mathrm{P}}$ & $\mathrm{NM}_{10 \mathrm{~N}, 3 \mathrm{P}}$ \\
\hline C15:0 & $0.65 \pm 0.09$ & $0.45 \pm 0.06$ & $0.64 \pm 0.11$ & $0.39 \pm 0.01$ & $0.69 \pm 0.08$ & $0.49 \pm 0.03$ & $0.38 \pm 0.04$ \\
\hline C15:1 & $0.43 \pm 0.1$ & $0.33 \pm 0.06$ & $0.60 \pm 0.17$ & $0.43 \pm 0.08$ & $0.30 \pm 0.06$ & $0.19 \pm 0.01$ & $0.13 \pm 0.04$ \\
\hline C16:0 & $22.05 \pm 0.52$ & $21.90 \pm 1.16$ & $21.86 \pm 0.49$ & $21.53 \pm 1.00$ & $23.97 \pm 0.62$ & $23.26 \pm 0.39$ & $26.35 \pm 2.76$ \\
\hline C16:1 (9Z) & $0.39 \pm 0.07$ & $0.37 \pm 0.03$ & $0.45 \pm 0.12$ & $0.41 \pm 0.05$ & $0.50 \pm 0.10$ & $0.60 \pm 0.07$ & $0.96 \pm 0.12$ \\
\hline C16:1 (11Z) & $0.03 \pm 0.01$ & $1.95 \pm 2.09$ & $0.04 \pm 0.01$ & $2.84 \pm 3.12$ & $0.04 \pm 0.01$ & $0.44 \pm 0.38$ & $0.07 \pm 0.03$ \\
\hline C18:0 & $3.43 \pm 0.06$ & $2.99 \pm 0.21$ & $3.30 \pm 0.09$ & $2.76 \pm 0.22$ & $3.58 \pm 0.14$ & $3.43 \pm 0.35$ & $3.96 \pm 0.58$ \\
\hline C18:1 (9Z) & $2.71 \pm 0.11$ & $2.26 \pm 0.16$ & $3.07 \pm 0.11$ & $2.54 \pm 0.14$ & $2.44 \pm 0.08$ & $2.09 \pm 0.19$ & $1.21 \pm 0.21$ \\
\hline C18:1 (11Z) & $0.71 \pm 0.09$ & $1.40 \pm 0.66$ & $0.78 \pm 0.07$ & $1.73 \pm 0.87$ & $0.89 \pm 0.15$ & $1.47 \pm 0.37$ & $2.52 \pm 0.59$ \\
\hline C18:2 (9Z, 12Z) & $50.38 \pm 0.26$ & $48.66 \pm 2.97$ & $49.01 \pm 1.00$ & $47.39 \pm 3.88$ & $49.47 \pm 0.57$ & $48.58 \pm 0.46$ & $44.61 \pm 2.84$ \\
\hline C18:3 (9Z, 12Z, 15Z) & $14.49 \pm 0.32$ & $15.18 \pm 0.43$ & $14.39 \pm 0.74$ & $15.27 \pm 1.24$ & $12.88 \pm 0.09$ & $13.44 \pm 0.45$ & $12.03 \pm 1.71$ \\
\hline C19:0 & $0.22 \pm 0.08$ & $0.36 \pm 0.11$ & $0.25 \pm 0.12$ & $0.53 \pm 0.28$ & $0.21 \pm 0.04$ & $0.55 \pm 0.06$ & $2.15 \pm 1.14$ \\
\hline C20:0 & $1.32 \pm 0.06$ & $1.19 \pm 0.26$ & $1.38 \pm 0.28$ & $1.09 \pm 0.19$ & $1.56 \pm 0.15$ & $1.80 \pm 0.19$ & $2.60 \pm 0.73$ \\
\hline C20:1 (11Z) & $0.34 \pm 0.04$ & $0.26 \pm 0.07$ & $0.37 \pm 0.01$ & $0.29 \pm 0.15$ & $0.34 \pm 0.10$ & $0.32 \pm 0.06$ & $0.27 \pm 0.05$ \\
\hline C20:1 (13Z) & $0.10 \pm 0.02$ & $0.10 \pm 0.00$ & $0.14 \pm 0.11$ & $0.11 \pm 0.04$ & $0.06 \pm 0.02$ & $0.09 \pm 0.05$ & $0.17 \pm 0.03$ \\
\hline C20:2 (11Z, 14Z) & $0.28 \pm 0.03$ & $0.22 \pm 0.04$ & $0.17 \pm 0.02$ & $0.20 \pm 0.05$ & $0.26 \pm 0.03$ & $0.18 \pm 0.04$ & $0.17 \pm 0.00$ \\
\hline $\mathrm{C} 21: 0$ & $0.68 \pm 0.07$ & $0.57 \pm 0.12$ & $0.68 \pm 0.07$ & $0.55 \pm 0.15$ & $0.88 \pm 0.07$ & $0.96 \pm 0.02$ & $1.23 \pm 0.16$ \\
\hline $\mathrm{C} 22: 0$ & $0.93 \pm 0.15$ & $0.96 \pm 0.27$ & $1.36 \pm 0.10$ & $0.90 \pm 0.10$ & $1.01 \pm 0.19$ & $1.13 \pm 0.13$ & $1.09 \pm 0.08$ \\
\hline $\mathrm{C} 23: 0$ & $0.37 \pm 0.05$ & $0.44 \pm 0.11$ & $0.50 \pm 0.12$ & $0.37 \pm 0.14$ & $0.35 \pm 0.07$ & $0.50 \pm 0.03$ & $0.45 \pm 0.08$ \\
\hline $\mathrm{C} 24: 0$ & $0.50 \pm 0.09$ & $0.42 \pm 0.14$ & $1.03 \pm 0.07$ & $0.69 \pm 0.02$ & $0.58 \pm 0.26$ & $0.48 \pm 0.13$ & $0.56 \pm 0.16$ \\
\hline
\end{tabular}

Tobacco plants were cultivated and membranes prepared as described (see legend Table 1). Fatty acids were determined and the proportion is given as molar percentage on total fatty acid. Data represent mean values $\pm \mathrm{SD}(n=3)$

${ }^{a}$ Molar percentage (total, 100) of fatty acids in membrane fractions of tobacco roots under different nutrient regime and colonised by $G$. mosseae (mean $\pm \mathrm{SD}$ of the proportion of total fatty acids)

content of nonadecanoic acid (19:0) and paullinic acid (20:1), which is ten and threefold enriched, respectively, in plants with well-supplied nutrients (Table 3).

\section{Plasma membrane nitrite-NO reductase activity}

Nitrite-NO reductase activity has been detected in all analysed pm fractions (derived from the PEG fraction). It became obvious that the rate of NO formation increased in parallel with nitrate supply of the plants, in both mycorrhizal and non-mycorrhizal plants (Fig. 2b). However, the mycorrhizal pm vesicles had an about twofold higher specific activity in plants supplied with 10 and $15 \mathrm{mM}$ nitrate in comparison to control plants. At $20 \mathrm{mM}$ nitrate supply, the highest and identical activity was measured after both treatments. Even higher external nitrate concentrations finally led to a decrease in activity, which was even stronger in the control plants than in mycorrhizal roots. The colonisation rate calculated for these treatments (Fig. 2a) is inversely correlated to specific NI-NOR activity (Fig. 2c) and followed a polynomial fit $(Y=0.73135-4.07475 X+$ $\left.5.98165 X^{2} ; r^{2}=0.923\right)$. The differences in membranebound NO formation activity were also in evidence in the microsomal fractions (Table 5). Under the applied conditions, only very little activity was detected (below $0.4 \%$ ) in the dextran fractions. The proportion of NI-NOR activity in the PEG fractions did not differ in samples gained from non-mycorrhizal roots (approximately 45\%). However, in comparison, a lower proportion of PEG phase-associated NI-NOR activity was detected in mycorrhizal roots under low nitrogen regime $\left(\mathrm{M}_{2 \mathrm{~N}, 0.1 \mathrm{P}}\right)$, and a shift to $68 \%$ was observed for mycorrhizal roots under $10 \mathrm{mM}$ nitrate supply $\left(\mathrm{M}_{10 \mathrm{~N}, 0.1 \mathrm{P}}\right)$.

\section{Discussion}

With individual plant sand cultures, establishing mycorrhizal symbiosis did not provide considerable advantages, certainly due to limited nutrient supply in the nutrient solution. AM fungi may provide the dominant route for plant phosphate supply, even when overall growth or phosphate uptake remains unaffected (Smith et al. 2003). To benefit plant growth under N-limiting conditions, AM fungi have to improve plant access to $\mathrm{N}$ to an extent sufficient to allow photosynthate production more than 
Table 3 Ratio of fatty acid distribution of $\mathrm{pm}$ vesicles (PEG fraction) that originated from mycorrhizal or nonmycorrhizal plants, depending on nitrogen and phosphate supply
Tobacco plants were cultivated and membranes prepared as described (see legend Table 1). The molar percentage of each fatty acid in pm vesicles is presented as the quotient of mycorrhizal roots $\left(\mathrm{M}_{2 \mathrm{~N}, 0.1 \mathrm{P}}\right)$ and control plants, as well as of plants well supplied with nutrients $\left(\mathrm{NM}_{10 \mathrm{~N}, 3 \mathrm{P}}\right)$ and plants with $\mathrm{N}$ and $\mathrm{P}$ limitation $\left(\mathrm{NM}_{2 \mathrm{~N}, 0.1 \mathrm{P}}\right)$, to distinguish between the effect of mycorrhiza and improved nutrient supply. Significant values are presented in bold using the $t$ test $(P<0.05)$

\begin{tabular}{|c|c|c|}
\hline \multirow[t]{2}{*}{ Fatty acid } & \multicolumn{2}{|c|}{ Ratio of fatty acid distribution of pm vesicles } \\
\hline & $\mathrm{M}_{2 \mathrm{~N}, 0.1 \mathrm{P}} / \mathrm{NM}_{2 \mathrm{~N}, 0.1 \mathrm{P}}$ & $\mathrm{NM}_{10 \mathrm{~N}, 3 \mathrm{P}} / \mathrm{NM}_{2 \mathrm{~N}, 0.1 \mathrm{P}}$ \\
\hline \multicolumn{3}{|c|}{ Minor variation caused by mycorrhiza or addition of $\mathrm{N}$ and $\mathrm{P}$} \\
\hline Palmitic acid C16:0 & $0.97 \pm 0.03$ & $1.10 \pm 0.10$ \\
\hline Stearic acid C18:0 & $0.96 \pm 0.09$ & $1.11 \pm 0.15$ \\
\hline Linoleic acid C18:2 (9Z, 12Z) & $0.98 \pm 0.01$ & $0.90 \pm \mathbf{0 . 0 5}$ \\
\hline$\alpha$-Linolenic acid C18:3 (9Z, 12Z, 15Z) & $1.04 \pm 0.03$ & $0.93 \pm 0.12$ \\
\hline Behenic acid C22:0 & $1.16 \pm 0.24$ & $1.12 \pm 0.21$ \\
\hline Lignoceric acid C24:0 & $0.96 \pm 0.49$ & $1.14 \pm 0.60$ \\
\hline \multicolumn{3}{|l|}{ Decrease caused by mycorrhiza and addition of $\mathrm{N}$ and $\mathrm{P}$} \\
\hline Pentadecanoic acid C15:0 & $\mathbf{0 . 8 4} \pm \mathbf{0 . 2 3}$ & $\mathbf{0 . 5 6} \pm \mathbf{0 , 0 8}$ \\
\hline cis-10-Pentadecenoic C15:1 & $\mathbf{0 . 6 3} \pm \mathbf{0 . 1 0}$ & $\mathbf{0 . 4 4} \pm \mathbf{0 . 1 3}$ \\
\hline Oleic acid C18:1 (9Z) & $\mathbf{0 . 8 6} \pm \mathbf{0 . 0 7}$ & $\mathbf{0 . 4 9} \pm \mathbf{0 . 0 8}$ \\
\hline cis-11, 14-Eicosadienoic acid C20:2 (11Z, 14Z) & $0.69 \pm 0.16$ & $\mathbf{0 . 6 7} \pm \mathbf{0 . 0 7}$ \\
\hline \multicolumn{3}{|l|}{ Increase caused by mycorrhiza and addition of $\mathrm{N}$ and $\mathrm{P}$} \\
\hline Palmitoleic acid C16:1 (9Z) & $1.21 \pm 0.24$ & $1.95 \pm 0.39$ \\
\hline Vaccenic acid C18:1 (11Z) & $1.69 \pm 0.44$ & $2.90 \pm 0.73$ \\
\hline Arachidic acid C20:0 & $1.16 \pm 0.14$ & $1.68 \pm 0.43$ \\
\hline Tricosanoic acid C23:0 & $1.45 \pm 0.24$ & $1.30 \pm 0.28$ \\
\hline \multicolumn{3}{|l|}{ Effects mainly caused by mycorrhiza } \\
\hline Palmitvaccenic acid C16:1 (11Z) & $11.96 \pm 9.22$ & $1.97 \pm 0.71$ \\
\hline \multicolumn{3}{|l|}{ Effects mainly caused by addition of $\mathrm{N}$ and $\mathrm{P}$} \\
\hline Gondoic acid C20:1 (11Z) & $1.00 \pm 0.28$ & $0.82 \pm 0.22$ \\
\hline Paullinic acid C20:1 (13Z) & $\mathbf{1 . 8 2} \pm \mathbf{0 . 9 7}$ & $3.23 \pm 0.98$ \\
\hline Nonadecanoic acid C19:0 & $2.61 \pm 0.43$ & $10.2 \pm 4.46$ \\
\hline Heneicosanoic acid C21:0 & $1.10 \pm 0.08$ & $1.40 \pm 0.19$ \\
\hline
\end{tabular}

Table 4 Distribution of palmitvaccenic acid in membrane fractions of mycorrhizal and non-mycorrhizal roots

\begin{tabular}{lll}
\hline Plant cultivation & \multicolumn{2}{l}{ Palmitvaccenic acid (\%) } \\
\cline { 2 - 3 } & $\begin{array}{l}\text { Dextran } \\
\text { fraction }\end{array}$ & $\begin{array}{l}\text { Polyethylenglycol } \\
\text { fraction }\end{array}$ \\
\hline Mycorrhizal $\left(\mathrm{M}_{2 \mathrm{~N}, 0.1 \mathrm{P}}\right)$ & $84.5 \pm 3.2$ & $15.5 \pm 3.2$ \\
Non-mycorrhizal $\left(\mathrm{NM}_{2 \mathrm{~N}, 0.1 \mathrm{P}}\right)$ & $51.2 \pm 2.9$ & $48.8 \pm 2.9$ \\
\hline
\end{tabular}

Tobacco plants were cultivated and membranes prepared as described (see legend Table 1). The distribution of palmitvaccenic acid [C16:1 (11Z)] is presented as mean value $\pm \operatorname{SD}(n=3)$ in relation to the microsomal fraction $(100 \%)$

fungal demand for photosynthate. Such mechanisms of $\mathrm{AM}$ fungi-mediated $\mathrm{N}$ acquisition include increased surface area for uptake or/and increased mineralisation of $\mathrm{N}$ from organic forms (Hodge 2001), which is not reasonable in individual sand culture systems. Yet, the effect of mycorrhiza on pm vesicles characteristics could be observed.

An enhancement in activity of $\mathrm{pm} \mathrm{H}^{+}$-ATPase measured in microsomal fractions of mycorrhizal plants has been reported before (Gianinazzi-Pearson et al.2000;
Benabdellah et al.1999) and might be related to energising transport processes at the periarbuscular membrane (Rosewarne et al. 2007). Generally, partitioning of microsomal fractions in the two-phase system results in an enrichment of right-side-out pm vesicles in the upper PEG phase, whereas the inside-out-orientated pm vesicles have higher affinity to the lower dextran phase (Larsson 1985). After partitioning the mycorrhizal microsomal fractions, an enrichment of the vanadate-inhibited $\mathrm{H}^{+}$-ATPase activity in the lower dextran phase was observed (Table 1). Possibly, this indicates a higher affinity of the periabuscular membrane with the enhanced $\mathrm{H}^{+}$-ATPase to the dextran phase similar to those of inside-out pm vesicles. Therefore, we conclude that pm vesicles enriched in the PEG phase probably originated from non-infected root cells, given that the pm vesicles were pure, as proven by marker enzyme activities (Table 1). The lower specific activity of vanadate-inhibited $\mathrm{H}^{+}$-ATPase in the PEG-containing $\mathrm{pm}$ fraction may reflect a diminished activity or presence of this enzyme in non-infected cells of mycorrhizal roots. Since mycorrhizal plants in low-phosphate soils attain much of their phosphate through a route provided by the fungus, plants will express transport-related proteins, 


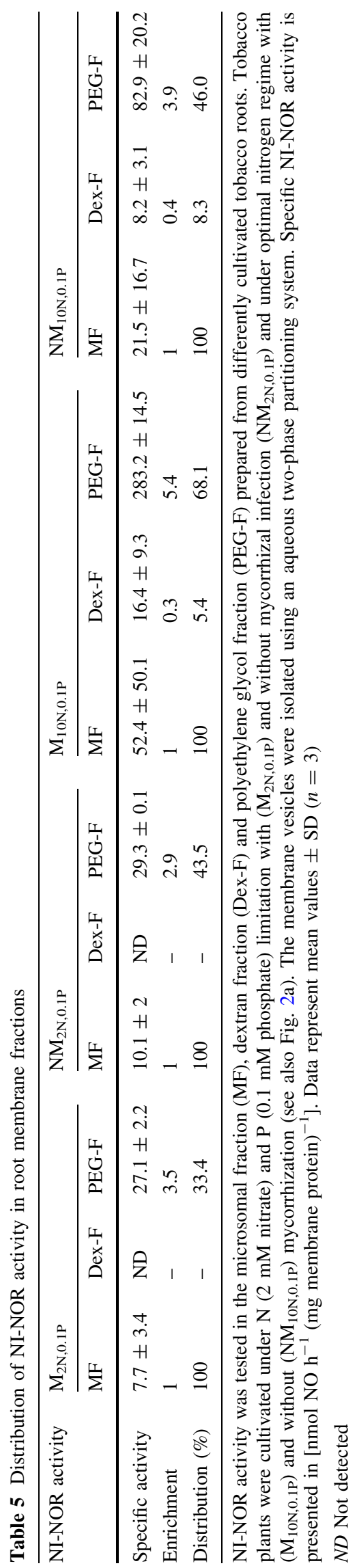

including $\mathrm{H}^{+}$-ATPases to energise transport processes, at the arbuscular interface to work most efficiently, whereas the expression of these proteins is generally reduced in non-inoculated cells (Rosewarne et al. 2007). However, it was also reported that AM fungi may induce a down-regulation of the root main systems of ATP consumption as a preparatory stage for root infection (Ramos et al. 2009). After the establishment of the AM colonisation, the fungi can induce reactivation for the reestablishment of healthy root growth and metabolism.

It has been frequently reported that palmitvaccenic acid is a reliable marker for intraradical fungal structures and is called a signature fatty acid. Trépanier et al. (2005) published the most comprehensive analysis of fatty acids occurring in lipids of $G$. intraradices spores. They demonstrated the presence of more than 20 components and emphasised the specificity of palmitvaccenic acid for the fungus. Palmitvaccenic acid was used also for AM fungal biomass estimation in roots and soil (e.g. Olsson and Johansen 2000; van Aarle and Olsson 2003; Stumpe et al.2005; Schliemann et al. 2008). Van Aarle and Olsson (2003) demonstrated that palmitvaccenic acid is not only a part of the neutral lipid fraction of storage lipids, but also present within phospholipids ( $P$. lanceolata with $G$. intraradices). Due to their analysis, it is possible to use this fatty acid also to assess a possible contamination of root pm vesicles by fungal membranes.

The very low palmitvaccenic acid level detected in nonmycorrhizal membrane fractions corresponded almost to technical detection limits and represents a constant background of 0.03-0.04 molar percentage. This value was used to estimate fungal contaminations within the mycorrhizal pm vesicles. In mycorrhizal microsomal fractions, palmitvaccenic acid was enriched by a factor of 65 in comparison to the non-mycorrhizal probe. In the dextran fraction, assumed to contain all plant endomembranes, inside-out pm vesicles and the fungal membranes, palmitvaccenic acids was enriched by a factor of 71 in comparison to the non-mycorrhizal control. This indicates an accumulation of fungal membranes in the dextran fraction compared to microsomal fraction (Table 4). Correspondingly, palmitvaccenic acid was only enriched by a factor of 11 in the PEG fraction containing pm vesicles from mycorrhizal roots, revealing a depletion of fungal membranes in comparison with the microsomal fraction. This demonstrates that the applied method is useful for the analysis of root pm vesicles in mycorrhizal roots. However, assuming all phospholipids of the membranes of $G$. mosseae would be made of palmitvaccenic acid $(100 \%)$, this would account for a fungal proportion of about $2 \%$ of all membranes in the microsomal root fraction. About $15 \%$ of the palmitvaccenic acid of the microsomal fraction was found in the pm fraction; this would make a minimum contamination 
$(0.3 \%)$ of the pm vesicles with fungal membranes. The exact proportion of palmitvaccenic acid in the pm of $G$. mosseae is not known due to experimental limitations. No further specific effect of mycorrhiza on pm fatty acid composition was observed. This finding supports our assessment that the pm vesicles originated from noninfected root cells.

Enzymatic pm-associated NO production of probably non-infected root cells under optimal nitrate supply was significantly higher than in non-mycorrhizal control plants. Almost half $(45 \%)$ of the activity detected in the microsomal fraction was recovered in the PEG fraction containing right-side-out $\mathrm{pm}$ vesicles. This supports our idea of NI-NOR, with activity sites located at the outer surface of the root pm. Consequently, no activity was found in the dextran phase-derived inside-out pm vesicles, indicating that NI-NOR had no access to the substrates. The distribution of NI-NOR activity in the PEG fractionderived pm vesicles from mycorrhizal roots differs highly. This indicates a fungal effect on the formation of insideout or right-side-out pm vesicles during the preparation procedure.

The increment in NI-NOR activity in mycorrhizal roots under optimal nitrogen regime may represent a mechanism in regulating mycorrhizal symbiosis related to plant demand for nitrogen. Mutualistic symbiosis, as established between plant roots and arbuscular mycorrhizal fungi, represents endosymbiotic interactions, including parasitism. As an obligate biotroph, AM fungi share similarities with biotrophic pathogens (Paszkowski 2006). Their arbuscules have a similar morphology as haustoria, which are formed by several pathogenic fungi during a compatible interaction. During both, haustorium and arbuscle formation, plant defence responses are induced, but in case of mutualistic associations only at a low level (García-Garrido and Ocampo 2002; Pozo and Azcón-Aguilar 2007). For these reasons, it seems likely that haustorium and arbuscle formations involve similar mechanisms (Albrecht et al. 1999). Defence mechanisms against biotrophic pathogens are generally co-ordinated by salicylic acid (reviewed by Pozo and Azcón-Aguilar 2007). Following the colonisation process in AM symbiosis from the extracellular to the intracellular growth of the microsymbiont, it seems likely that the plant defence responses might change during the colonisation process and that these modifications could be mediated through a cross-talk between salicylic acid and jasmonates-dependent signalling pathways (reviewed by Pozo and Azcón-Aguilar 2007). Possibly, the NO production by NI-NOR in roots, the activity of which is dependent on nitrate availability in the soil, affects development of pathogens and of AM. NO, as a signalling molecule in AM symbiosis and its detoxification by haemoglobins in arbuscule-containing cells, was addressed by Vieweg et al.
(2005). It can be speculated that high local levels of apoplastic NO might lead either to a direct affection of the fungus or induce defence responses (Klessig et al.2000) followed by poor or even no colonisation of the plant at higher nitrate supply.

We suggest that under detrimental high nitrate supply (Stöhr 1999), the defence system of the plant is impaired, including NO production, thereby assisting the progress of invading hyphae. We hypothesise a coordinated activity of PM-NR and NI-NOR at the root pm, with nitrate being reduced to nitrite by PM-NR and subsequently to NO by NINOR. As demonstrated for NI-NOR activity, also PM-NR activity increased with external nitrate supply as described earlier (Stöhr 1999). However, no significant differences between mycorrhizal and non-mycorrhizal plants have been found (data not shown). Since NI-NOR and PM-NR have been demonstrated to act independently and can be separated by chromatographic techniques (Stöhr et al. 2001), slightly different responses to environmental factors may be assumed. It became obvious that the decrease in NI-NOR activity occurred already at a nitrate concentration of $25 \mathrm{mM}$, instead of at an earlier observed concentration of $40 \mathrm{mM}$ nitrate (Stöhr and Stremlau 2006). We conclude that this effect was caused by the reduced phosphate concentration applied in the presented experiments.

\section{Concluding remarks}

The pm vesicles isolated with the aqueous two-phase system from mycorrhizal roots originated probably from non-infected cortex cells. This was concluded from the distribution of pm ATPase activity and lipid composition. The $\mathrm{pm}$ vesicles displayed a high NI-NOR activity, indicating that those cells that produce apoplastic NO are not infected. Further studies may reveal the role of NO in the mycorrhizal infection process as well as persistence in the plant.

Open Access This article is distributed under the terms of the Creative Commons Attribution Noncommercial License which permits any noncommercial use, distribution, and reproduction in any medium, provided the original author(s) and source are credited.

\section{References}

Akiyama K, Matsuzaki K, Hayashi H (2005) Plant sesquiterpenes induce hyphal branching in arbuscular mycorrhizal fungi. Nature 435:824-827

Albrecht C, Geurts R, Bisseling T (1999) Legume nodulation and mycorrhizae formation; two extremes in host specificity meet. EMBO J 18:281-288

Balestrini R, Berta G, Bonfante P (1992) The plant nucleus in mycorrhizal roots: positional and structural modifications. Biol Cell 75:235-243 
Benabdellah K, Azcón-Aguilar C, Ferrol N (1999) Plasma membrane ATPase and $\mathrm{H}^{+}$transport activities in microsomal membranes from mycorrhizal tomato roots. J Exp Bot 50:1343-1349

Bonfante P, Perotto S (1995) Strategies of arbuscular mycorrhizal fungi when infecting host plants. New Phytol 130:3-21

Bradford MM (1976) A rapid and sensitive method for the quantification of microgram quantities of protein utilizing the principle of protein-dye binding. Anal Biochem 72:248-254

Chalot M, Blaudez D, Brun A (2006) Ammonia: a candidate for nitrogen transfer at the mycorrhizal interface. Trends Plant Sci 11:263-266

Delledonne M, Xia Y, Dixon RA, Lamb C (1998) Nitric oxide signal functions in plant disease resistance. Nature 394:585-588

Duke SE, Jackson B, Caldwel ML (1994) Local reduction of mycorrhizal arbuscule frequency in enriched soil microsites. Botany 72:998-1001

Durner J, Wendehenne D, Klessig DF (1998) Defense gene induction in tobacco by nitric oxide, cyclic GMP, and cyclic ADP ribose. Proc Natl Acad Sci USA 95:10328-10333

Eriksson $\AA$ (2001) Arbuscular mycorrhiza in relation to management history, soil nutrients and plant species diversity. Plant Ecol 155:129-137

Ezawa T, Smith SE, Smith FA (2002) P metabolism and transport in AM fungi. Plant Soil 244:221-230

Furlan V, Bernier-Cardou M (1989) Effects of N, P, and K on formation of vesicular-arbuscular mycorrhizae, growth and mineral-content of onion. Plant Soil 113:167-174

García-Garrido JM, Ocampo JA (2002) Regulation of the plant defence response in arbuscular mycorrhizal symbiosis. J Exp Bot 53:1377-1386

Genre A, Chabaud M, Timmers T, Bonfante P, Barker DG (2005) Arbuscular mycorrhizal fungi elicit a novel intracellular apparatus in Medicago truncatula root epidermal cells before infection. Plant Cell 17:3489-3499

Gianinazzi-Pearson V, Arnold C, Oufattole M, Arango M, Gianinazzi S (2000) Differential activation of $\mathrm{H}^{+}$-ATPase genes by an arbuscular mycorrhizal fungus in root cells of transgenic tobacco. Planta 211:609-613

Govindarajulu M, Pfeffer PE, Jin H, Abubaker J, Douds DD, Allen JW, Bücking H, Lammers PJ, Shacher-Hill Y (2005) Nitrogen transfer in the arbuscular mycorrhiza symbiosis. Nature 435:819-823

Harrison M (1999) Molecular and cellular aspects of the arbuscular mycorrhizal symbiosis. Annu Rev Plant Physiol Plant Mol Biol 50:361-389

Hause B, Mrosk C, Isayenkov S, Strack D (2007) Jasmonates in arbuscular mycorrhizal interactions. Phytochemistry 68:101-110

Hodge A (2001) Arbuscular mycorrhizal fungi influence decomposition of, but not plant nutrient capture from, glycine patches in soil. New Phytol 151:725-734

Hodges TK, Leonard RT (1974) Purification of a plasma membranebound adenosine triphosphatase from plant roots. Methods Enzymol 32:392-406

Klessig DF, Durner J, Noad R, Navarre DA, Wendehenne D, Kumar D, Zhou JM, Shah J, Zhang S, Kachroo P, Trifa Y, Pontier D, Lam E, Silva H (2000) NO and salicylic acid signaling in plant defense. Proc Natl Acad Sci USA 97:8849-8855

Lanzetta PA, Alvarez LJ, Reinach PS, Candia OA (1979) An improved assay for nanomole amounts of inorganic phosphate. Anal Biochem 100:95-97

Larsson C (1985) Plasma membranes. In: Linkens HF, Jackson JF (eds) Modern methods of plant analysis. Springer, Berlin, pp 85-104

McGonigle TP, Miller MH, Evans DG, Fairchild GL, Swan JA (1990) A new method which gives an objective measure of colonisation of roots by vesicular-arbuscular mycorrhizal fungi. New Phytol 115:495-501
Menéndez A, Larsson C, Ugalde UO (1995) Purification of functionally sealed cytoplasmic side-out plasma membrane vesicles from Saccharomyces cerevisiae. Anal Biochem 230:308-314

Menge JA, Steirle D, Bagyaraj DJ, Johnson ELV, Leonard RT (1978) Phosphorus concentrations in plants responsible for inhibition of mycorrhizal infection. New Phytol 80:575-578

Olsson PA, Johansen A (2000) Lipid and fatty acid composition of hyphae and spores of arbuscular mycorrhizal fungi at different growth stages. Mycol Res 104:429-434

Olsson PA, Bååth E, Jakobsen I (1997) Phosphorus effects on the mycelium and storage structures of an arbuscular mycorrhizal fungus as studied in the soil and roots by analysis of fatty acid signatures. Appl Environ Microbiol 63:3531-3538

Paszkowski U (2006) Mutualism and parasitism: the yin and yang of plant symbiosis. Curr Opin Plant Biol 9:364-370

Pozo MJ, Azcón-Aguilar C (2007) Unraveling mycorrhiza-induced resistance. Curr Opin Plant Biol 10:393-398

Ramos AC, Martins MA, Okorokova-Façanha AL, Olivares FL, Okorokov LA, Sepúlveda N, Feijó JA, Façanha AR (2009) Arbuscular mycorrhizal fungi induce differential activation of the plasma membrane and vacuolar $\mathrm{H}^{+}$pumps in maize roots. Mycorrhiza 19:69-80

Reinhardt D (2007) Programming good relations-development of the arbuscular mycorrhizal symbiosis. Curr Opin Plant Biol 10:98-105

Rosewarne GM, Smith FA, Schachtman DP, Smith SE (2007) Localization of proton-ATPase genes expressed in arbuscular mycorrhizal tomato plants. Mycorrhiza 17:249-258

Schliemann W, Ammer C, Strack D (2008) Metabolite profiling of mycorrhizal roots of Medicago truncatula. Phytochemistry 69:112-146

Schüßler A, Schwarzott D, Walker C (2001) A new fungal phylum, the Glomeromycota: phylogeny and evolution. Mycol Res 105:1413-1421

Schüßler A, Martin D, Cohen D, Fitz M, Wipf D (2007) Studies on the geosiphon symbiosis lead to the characterization of the first Glomeromycotan sugar transporter. Plant Signal Behav 2:314317

Shepherd MG (1987) Cell envelope of Candida albicans. Crit Rev Microbiol 15:7-25

Siciliano V, Genre A, Balestrini R, Cappellazo G, deWit PJ, Bonfante $P$ (2007) Transcriptome analysis of arbuscular mycorrhizal roots during development of the penetration apparatus. Plant Physiol 144:1455-1466

Smith SE, Smith FA (1990) Structure and function of the interfaces in biotrophic symbioses as they relate to nutrient transport. New Phytol 114:1-38

Smith SE, Smith FA, Jakobsen I (2003) Mycorrhizal fungi can dominate phosphate supply to plants irrespective of growth responses. Plant Physiol 133:16-20

Stöhr C (1999) Relationship of nitrate supply with growth rate plasma membrane-bound and cytosolic nitrate reductase, and tissue nitrate content in tobacco plants. Plant Cell Environ 22:169-177

Stöhr C, Stremlau S (2006) Formation and possible roles of nitric oxide in plant roots. J Exp Bot 57:463-470

Stöhr C, Ullrich WR (1997) A succinate-oxidising nitrate reductase is located at the plasma membrane of plant roots. Planta 203:129 132

Stöhr C, Strube F, Marx G, Ullrich WR, Rockel P (2001) A plasma membrane-bound enzyme of tobacco roots catalyzes the formation of nitric oxide from nitrite. Planta 212:835-841

Stumpe M, Carsjens J-G, Stenzel I, Göbel C, Lang I, Pawlowski K, Hause B, Feussner I (2005) Lipid metabolism in arbuscular mycorrhizal roots of Medicago truncatula. Phytochemistry $66: 781-791$ 
Surjus A, Durand M (1996) Lipid changes in soybean root membranes in response to salt treatment. J Exp Bot 47:17-23

Tobar RM, Azcón R, Barea JM (1994) Improved nitrogen uptake and transport from $15 \mathrm{~N}$-labelled nitrate by external hyphae of arbuscular mycorrhiza under water-stressed conditions. New Phytol 126:119-122

Trépanier M, Bécard G, Moutoglis P, Willemot C, Gagné S, Avis TJ, Rioux JA (2005) Dependence of arbuscular-mycorrhizal fungi on their plant host for palmitic acid synthesis. Appl Environ Microbiol 71:5341-5347

Uehlein N, Fileschi K, Eckert M, Bienert GP, Bertl A, Kaldenhoff R (2007) Arbuscular mycorrhizal symbiosis and plant aquaporin expression. Phytochemistry 68:122-129

Valot B, Negroni L, Zivy M, Gianinazzi S, Dumas-Gaudot E (2006) A mass spectrometric approach to identify arbuscular mycorrhiza-related proteins in root plasma membrane fractions. Proteomics 6:145-155 van Aarle IM, Olsson PA (2003) Fungal lipid accumulation and development of mycelial structures by two arbuscular mycorrhizal fungi. Appl Environ Microbiol 69:6762-6767

Vierheilig H, Schweiger P, Brundrett M (2005) An overview of methods for the detection and observation of arbuscular mycorrhizal fungi in roots. Physiol Plant 125:393-404

Vieweg MF, Hohnjec N, Küster H (2005) Two genes encoding different truncated hemoglobins are regulated during root nodule and arbuscular mycorrhiza symbioses of Medicago truncatula. Planta 220:757-766

Weidmann S, Sanchez L, Descombin J, Chatagnier O, Gianinazzi S, Gianinazzi-Pearson V (2004) Fungal elicitation of signal transduction-related plant genes precedes mycorrhiza establishment and requires the dmi3 gene in Medicago truncatula. Mol Plant Microbe Interact 17:1385-1393 